Artikel untuk Jurnal MKU.

\title{
ISLAM DAN KEARIFAN BERBUDAYA Menggali Filsafat Dakwah Sunan Kalijaga
}

\section{Oleh: H. Zainal Arifin Thoha}

“Ajaklah mereka kepada jalan Tuhanmu dengan hikmat kebijaksanaan dan pengajaran yang baik, dan bertukar pikiranlah dengan mereka dengan cara yang sebaik-baiknya" (QS. An-Nahl, 16:125).

"Maka dengan rahmat Allah-lah engkau (Muhammad) berlaku lemah lembut kepada mereka, dan sekiranya engkau keras hati, niscaya mereka berpisah dari sekelilingmu, maka berilah maaf mereka, dan mohonkanlah ampunan atas segala kekhilafan mereka, dan bermusyawarahlah dengan mereka dalam berbagai urusan, maka apabila engkau telah mengambil keputusan, bertawakallah kepada Allah, sesungguhnya Allah mencintai orang-orang yang bertawakal" (QS. Ali Imran, 3:159).

"Perumpamaan orang-orang mukmin dalam berkasih-sayangnya seperti satu tubuh, apabila satu bagian dari tubuh itu merasa sakit, maka seluruh tubuh itu pun turut merasakan sakitnya dengan tidak bisa tidur dan demam" (Al-Hadits).

"Tidaklah sempurna iman seseorang, sehingga ia menyayangi sesamanya sebagaimana ia menyayangi dirinya sendiri” (Al-Hadits).

"Tidaklah bisa disebut generasi sejati, orang muda yang mengatakan inilah bapakku, melainkan generasi sejati itu ialah orang yang lantang berkata inilah aku!" (Ali bin Abu Thalib).

"Seburuk-buruk manusia ialah orang-orang yang malas, yang apabila engkau ungguli mereka menyebut jasa-jasa nenek-moyangnya; dan sebaik-baik manusia ialah mereka yang mempunyai kemuliaan masa lalu, sedang mereka sendiri berusaha menegakkan kemuliaan yang baru” (Imam Syauqi Bey). $* * *$

Alkisah, suatu hari Sunan Kalijaga tengah mengembara. Beliau melewati sebuah hutan, dan mendapati seekor katak tengah berada dalam mulut seekor ular, 
hendak dimangsa. Demi menyaksikan hal itu, secara spontan Sunan Kalijaga berteriak: "Hu!!!"

Mendengar teriakan itu, si ular lengah, dan katak pun segera melompat keluar dari mulut ular.

Sunan Kalijaga meneruskan pengembaraan, namun sekonyong-konyong beliau menyaksikan ada ular yang menghadang perjalanannya.

"Mengapa engkau menghalau rezeki dari Allah yang telah menjadi hakku?" Ular itu ternyata adalah ular yang tadi hendak memangsa katak.

"Sungguh aku tak bermaksud begitu," jawab Sunan Kalijaga tenang, "malahan sebaliknya aku menyuruhmu dengan teriakan $\mathrm{Hu}$ itu, Huntalen, segera telanlah."

Mendengar penjelasan itu, si ular malu, ia pun pergi setelah memohon maaf kepada Sunan Kalijaga.

Sunan Kalijaga meneruskan langkah, namun katak pun menghadang perjalanan beliau.

"Kenapa Anda tak segera menolong saya, sewaktu saya tengah dalam kondisi kritis di mulut ular?” Katak melakukan protes terhadap Sunan Kalijaga.

"Sungguh aku tak bermaksud begitu," jelas Sunan Kalijaga dengan penuh pengertian, "malahan aku sebaliknya menyuruhmu dengan teriakan $H u$ itu, untuk Huculo, segera lepaslah."

Sebagaimana ular si ular di atas, katak pun meminta maaf atas kekhilafannya kepada Sunan Kalijaga.

$* * *$

Anda mungkin menertawai keluguan dua ekor binatang melata itu. Tetapi apakah Sunan Kalijaga menertawakan reaksi kedua binatang, yang kita anggap lugu itu?

Kita mungkin menganggap, jawaban Sunan Kalijaga atas kedua binatang melata itu bohong belaka.

Maka, benarkah Sunan Kalijaga telah melakukan dusta atas hewan melata itu? 
Mari kita menyimak ayat-ayat maupun hadits Nabi Saw di atas. Dengan menyimak dan merenungkan ayat-ayat serta hadits di atas, Insya Allah kita akan mengetahui dan mengerti, bahwa seorang alim (ulama') dan seorang wali (awliya'), seperti Sunan Kalijaga, tentulah jauh dari sifat-sifat tercela, semacam dusta. Akan tetapi, dusta untuk suatu kebaikan dan kebenaran, bukankah diperbolehkan?

Betul. Tetapi untuk apa Sunan Kalijaga berdusta. Bukankah telah menjadi Sunnatullah, bahwa katak memang sebenarnyalah makanan ular. Dan andai pun katak itu betul-betul dimakan oleh ular pada saat itu, maka telah menjadi takdir dari Allah SWT pula hal itu terjadi.

Menurut hemat saya, sebagaimana ayat-ayat dan hadits di atas, dalam diri seorang yang telah qarib dengan Tuhan, seperti Sunan Kalijaga, tentu memiliki perasaan atau hati yang pengasih, yang penyayang, yang tidak tega menyaksikan fenomena kekerasan atau pembunuhan --dalam mata pandang nuranikemanusiaan.

Kasih dan sayangnya itulah yang melahirkan spontanitas, suatu energi actual yang lahir melalui kehendak Ilahi, dan dengan cahaya-petunjuk Ilahi pula Sunan Kalijaga menerangkan sikap atau tindakannya.

$* * *$

Baik, Anda mungkin menyangka saya melakukan filsafat othak-athikmathuk. Walau pun filsafat (Jawa) ini tidak keliru, sebab kekeliruan itu justru seringkali lahir dari sikap sirik --bukan syirk-dan su'udhan, namun acapkali filsafat semacam itu dianggap tidak rasional dan tidak proporsional.

Sekali lagi, baik, kita tinggalkanlah frame positivisme semacam itu, dan kita kembali kepada teladan Sunan Kalijaga. Dalam fragmen atau alegori di atas, Sunan Kalijaga secara spontan meneriakkan, “Hu!!!”. Bukankah ini khas ucapan kaum sufi, yang oleh para peneliti digolongkan ke dalam sufi ittihad, atau di tanah Jawa dikenal dengan istilah "Manunggaling Kawula Gusti”.

Ya, ucapan “ $H u$ ”, bukanlah sekedar ucapan, melainkan ungkapan, bahkan ungkapan murni yang terdalam, “Hu-Allah”. Dan ungkapan murni yang spontan itu hanya mungkin terekpresi keluar dari orang yang memang telah memiliki 
kedalaman kemurnian, yakni orang yang telah menyatukan diri atau dipersatukan dengan atau oleh Sang Maha Rahman Sang Maha Rahim, yang kasih sayangnya telah menjentara ke segenap ufuk cakrawala beserta anasir-anasirnya, bahkan melampauinya.

$* * *$

Dakwah yang mengedepankan kasih sayang itulah, yang bisa melahirkan kearifan. "Man 'arafa nafsahu faqad 'arafa rabbahu wa man 'arafa rabbahu faqad 'arafa nafsahu”; Barangsiapa mengerti akan dirinya maka ia mengerti akan Tuhannya dan barangsiapa mengerti akan Tuhannya maka ia mengerti akan dirinya.

Hal yang perlu kita mengerti, manusia itu sendiri, bukanlah sekadar terdiri dari akal budi -yang merupakan refleksi dari dimensi pengetahuan atau kearifan ('arafa) dan tercermin dalam terminology ilmul-yaqin-melainkan juga fisikjasmani (nafsahu) yang merupakan refleksi dari dimensi materi dan tercermin dalam terminology 'ainul-yaqin, juga terutama terdiri dari atau bagian dari hakikat-sejati (rabbahu) yang merupakan refleksi dari dimensi ruhani dan tercermin dalam terminology haqqul-yaqin.

Kebudayaan, demikian kalau kita menggunakan terminologinya Prof. Dr. Koentjaraningrat (1974), dibedakan dalam tiga wujud: pertama, wujud kebudayaan sebagai suatu kompleks dari ide-ide, gagasan, nilai-nilai, normanorma, peraturan, dan sebagainya; kedua, wujud kebudayaan sebagai suatu kompleks aktivitas kelakuan yang berpola dari manusia di dalam masyarakat; dan ketiga, wujud kebudayaan sebagai benda-benda hasil karya manusia.

Berdasarkan hal itu, maka kearifan kultural yang belakangan menjadi trend dunia global abad 21, sesungguhnya barulah menapak atau merangkum dua potensi dasar dari fitrah manusia. Dengan demikian, ia masih membutuhkan penyempurnaan dari kita, dari generasi kini, dari (ajaran) Islam.

Apa yang telah diteladankan Sunan Kalijaga dalam titian strategi dakwahnya, sesungguhnya telah mendahului zamannya, dimana ESQ (Emotional Spiritual Quantion) belum digembor-gemborkan seperti sekarang ini. Dan ini 
memang sesuai dengan filsafat dakwah Sunan Kalijaga, yang tersimpul dalam 'nyanyi-sunyi sang sufi' itu sendiri:

\section{Kidung Rumekso ing Wengi}

“Ana kidung rumeksa ing wengi

Teguh ayu luputa ing lelara

Luputa bilahi kabeh

Jim setan datan purun

Paneluhan tan ana wani

Miwah panggawe ala

Gunaning wong luput

Geni atemahan tirta

Maling adoh tan ana ngarah mring sami

Guna duduk pan sirna

Sakabehing lara pan samya bali

Sakeh ngama pan sami miruda

Welas asih pandulune

Sakehing braja luput

Kadi kapuk tibaning wesi

Sakehing wisa tawa

Sato galak lulut

Kayu aeng lemah sangar

Songing landhak guwaning wong lemah miring

Myang pokiponing merak

Pagupakaning warak sakalir

Nadyan arca myang segara asat

Temahan rahayu kabeh

Apan sarira ayu 
Ingideran kang widadari

Rineksa malaikat

Sakathahing rasul

Pan dadi sarira tunggal

Ati Adan utekku Baginda Esis

Pangucapku ya Musa

Napasku Nabi Musa linuwih

Nabi Yakub pamyarsaningwang

Yusup ing rupaku mangke

Nabi Dawud swaraku

Jeng Suleman kasekten mami

Nabi Ibrahim nyawaku

Edris ing rambutku

Bagendha Li kulitingwang

Getih daging Abu Bakar singgih

Balung Bagendha Usman

Sungsumingsun Patimah linuwih

Sati Aminah bayuning angga

Ayub ing ususku mangke

Nabi Nuh ing jejantung

Nabi Yunus ing otot mami

Netraku ya Muhammad

Pamuluku rasul

Pinayungan Adam sarak

Sampun pepak sakathahing para nabi

Dadya sarira tunggal

Wiji sawiji mulune dadi 
Apan pencar saisining jagad

Kasamadan dening date"

Jika hendak kita urai, dengan pendekatan hermeneutik, maka ungakapan judul "Kidung Rumekso ing Wengi" itu, bukankah suatu kegembiraan yang terkendali (khusyu'), suatu cinta menggelora (mahabbah) yang tulus (ikhlash). Inilah sesungguhnya tasawuf Islam itu, yang merupakan akhlaq dari orang yang 'mengerti' (ma'rifat); “Takhallaquu bi akhlaqillaah”, Berakhlaqlah engkau dengan akhlaq Allah (Al-Hadits); "Wa-innaka la'alaa khuluqin 'adhiim”, Dan sesungguhnya engkau (Muhammad) benar-benar berbudi pekerti yang agung (QS. Al-Qalam, 68:4); “Innamaa bu'itstu li-utammima makaarimal-akhlaaq”, Sesungguhnya aku diutus untuk menyempurnakan kemuliaan akhlaq (Al-Hadits).

Menurut Ahmad Muhammad al-Hufy dalam kitabnya Min AkhlaqinNabiy, ada 19 hal yang menonjol dari akhlaq Nabi Muhammad Saw, meliputi: (1) Keberanian, asy-Syaja'ah; (2) Pemurah, al-Karam; (3) Adil, al-'Adl; (4) Mengendalikan diri, al'Iffah; (5) Benar, ash-Shidq; (6) Amanah, al-Amanah; (7) Sabar, ash-Shabr; (8) Lapang hati, al-Hilm; (9) Pemaaf, al-'Afw; (10) Kasih saying, ar-Rahman; (11) Mengutamakan perdamaian, Itsaarus-Salam; (12) Zuhud, az-Zuhd; (13) Malu, al-Haya'; (14) Rendah hati, at-Tawadlu'; (15) Setia, al-Wafa; (16) Musyawarah, asy-Syura; (17) Baik dalam pergaulan, Thibul-Isyrah; (18) Cinta bekerja, Hubbul-Amal; dan (19) Humoris, al-Bisyru wal-Fukahah.

Akhlaq yang telah diteladankan Nabi Muhammad Saw ini, rupanya juga dijalani oleh Sunan Kalijaga, dan ini dapat kita simak dari sirah Sunan Kalijaga berikut cerita turun-temurun yang terefleksi di dalam kearifan cultural yang hingga kini masih terwarisi dengan cukup baik, terutama oleh masyarakat tradisionalis Jawa, juga juga dapat kita lihat dari jejak-jejak arkeologis maupun historiografis.

Islam dan kearifan berbudaya, secara simbolik juga tercermin dari filsafat dakwah khas Sunan Kalijaga berikut ini, yang bisa dikatakan sebagai dakwahfadilah dan merupakan tuntunan atas "Kidung Rumekso ing Wengi” di atas. 
Kang maca kang angrungu

Kang anurat kang anyimpeni

Dadi ayuning badan

Kinarya sesembur

Yen winacakna ing toya

Kinarya dus rara gelis laki

Wong edan nuli waras

Lamun ana wong kadendha kaki

Wong kabandha wong kabotan utang

Yogya wacanen den age

Nalika tengah dalu

Ping sawelas macanen singgih

Luwar saking kabanda

Kang kadendha wurung

Aglis nuli sinauran mring Hyang

Suksma kang utang puniku singgih

Kang agring nuli waras

Lamun arsa tulus nandur pari

Puwasa sawengi sadina

Iderana galengane

Wacanen kidung iku

Sakeh ngama sami abali

Yen sira lunga perang

Wateken ing sekul

Antuka tigang pulukan

Musuhira rep sirep tan ana wani

Rahayu ing payudan

Sing sapa reke bisa nglakoni

Amutiya lawan anawa 
Patang puluh dina wae

Lan tangi wektu subuh

Lan den sabar sukuring ati

Insya Allah tinekan

Sakarsanireku

Tumrap sanak rakyatira

Saking sawabing ngelmu pangiket mami

Duk aneng Kalijaga

Dengan memperhatikan tuntunan tersebut, kita jadi tahu, betapa "dakwahfadilah" yang dilakukan Sunan Kalijaga hendak merangkum, merangkul, dan mengayomi berbagai kecenderungan maupun berbagai strata social masyarakat, baik mereka yang memiliki kemampuan atau pun kecenderungan untuk membaca (kang maca), mendengarkan (kang angrungu), menulis (kang anurat), atau pun menyimpan (kang anyimpeni). Ya, semuanya mendapat tempat di hati Sunan Kalijaga, dan semua merasa mendapatkan perhatian istimewa dari Sunan Kalijaga, dan beliau pun memang memperhatikan dengan sungguh-sungguh apa yang dialami, dipikirkan, dan dirasakan oleh masyarakatnya.

Lantaran itu, tidak mengherankan, apabila Sunan Kalijaga bukan hanya menjadi Pahlawan, namun lebih dari itu beliau adalah "Bapak Ruhani Orang Jawa". Wallahu a'lam bish-shawab.***

*) H. Zainal Arifin Thoha, Dosen PAI pada UPT-MKU Universitas Negeri Yogyakarta (UNY). 